Miguel John Versluys (ed.)

BEYOND EGYPTOMANIA

Objects, Style and Agency 
STUDIEN AUS DEM WARBURG-HAUS, BAND 21

Herausgegeben von

Uwe Fleckner

Margit Kern

Birgit Recki

Cornelia Zumbusch

REIHE "KUNST UND WIRKMACHT / ART AND AGENCY«

Herausgegeben von

Caroline van Eck

Uwe Fleckner 
Miguel John Versluys (ed.)

\section{BEYOND EGYPTOMANIA}

Objects, Style and Agency

\section{DE GRUYTER}


This volume is cordially dedicated to Professor Jan Assmann,

on the occasion of his $80^{\text {th }}$ birthday 